\title{
International Tournal of \\ Effect of yogic exercises on flexibility and co-ordination of football players
}

DABIR QURESHI

Received : 22.07.2014; Accepted : 30.09.2014

Author for correspondence :

DABIR QURESHI

Shri Shivaji College of Physical

Education, AMRAVATI (M.S.) INDIA

\section{-ABSTRACT}

Football is one of the most popular sports in the world. It appeals to all age groups of various skill levels, and men and women play it for recreation as well as competition. Flexibility and co-ordination play important role for the development of football skills. It has been observed from the result of the finding of this study that the experimental group had shown significant improvement in flexibility and coordinative ability compared to control group, it may be because of due to nature of regular yogic exercises. The regular yogic exercises might have developed the muscle tone, joint mobility and neuro-muscular coordination. Hence a significant improvement in the performance has shown in the selected subjects.

- Key Words : Yogic exercise, Flexibility and co-ordination, Football players

- How to cite this paper : Qureshi, Dabir (2014). Effect of yogic exercises on flexibility and co-ordination of football players. Internat. J. Phy. Edu., 7 (2) : 86-87. 